\title{
De Tijdelijke wet transparantie turboliquidatie: een doekje voor het bloeden
}

\author{
Dr. S. Rensen*
}

\begin{abstract}
In deze bijdrage wordt het conceptwetsvoorstel Tijdelijke wet transparantie turboliquidatie onder de loep genomen. Hoewel het transparantiegebrek rondom turboliquidaties hiermee grotendeels lijkt te worden opgelost, blijft het daadwerkelijke probleem - de fraudegevoeligheid van de ontbindingswijze - bestaan.
\end{abstract}

\section{Inleidend}

Ruim voordat de COVID-19-pandemie uitbrak, gaf minister Dekker naar aanleiding van Kamervragen aan het fenomeen turboliquidatie nader te zullen bestuderen. ${ }^{1}$ De Kamervragen ontstonden tijdens een debat over fraudebestrijding in ondernemingsrechtelijke sferen, en naar aanleiding van de huidige praktijk, waarin turboliquidaties veelvuldig worden toegepast. Deze verkenning van de inmiddels meest beruchte ontbindingswijze van het Nederlandse rechtssysteem heeft uiteindelijk geresulteerd in een Kamerbrief, waarin de minister beloofde een wetsvoorstel voor te bereiden. ${ }^{2}$ Ook deze belofte werd al een aantal maanden voordat de uitbraak van de pandemie plaatsvond gedaan. Het is op zijn minst eigenaardig te noemen dat het uiteindelijke conceptwetsvoorstel wordt gelinkt aan de COVID-19-pandemie en daardoor ook een tijdelijk karakter draagt. Hierover later in deze bijdrage meer. ${ }^{3}$ Het centraal staande fenomeen - in de praktijk aangeduid als turboliquidatie - is een onderwerp waarover ik de afgelopen jaren veel geschreven heb en waarover ook veel geprocedeerd is. Turboliquidatie is de benaming die is gegeven aan de ontbindingswijze als bedoeld in artikel 2:19 lid 4 BW: wanneer een rechtspersoon ten tijde van ontbinding geen baten heeft, houdt deze alsdan op te bestaan. Het direct ophouden te bestaan heeft als gevolg dat er geen vereffeningsfase als bedoeld in artikel 2:23 e.v. BW plaatsvindt. Wanneer een rechtspersoon wordt ontbonden zonder toepassing van artikel 2:19 lid $4 \mathrm{BW}$, geldt op grond van het vijfde lid van voormelde bepaling dat de rechtspersoon na ontbinding blijft voortbestaan. Pas na beëindiging

\footnotetext{
* Dr. S. Renssen is universitair docent Ondernemings- en Insolventierecht aan Maastricht University, Visiting Assistant Professor aan de China European Union School of Law, Beijing en redactielid van het TvOB.

1 Kamerstukken II 2018/19, 29911, nr. 210, p. 19.

2 Kamerstukken II 2019/20, 29911, nr. 253.

3 Zie par. 2.3 en 4
}

van de vereffeningsfase houdt de rechtspersoon op te bestaan. ${ }^{4}$ Het ontbreken van een formele vereffening betekent echter niet dat er helemaal geen vereffening plaatsvindt in het geval van turboliquidatie. ${ }^{5}$ Er zal telkens voorafgaand aan het nemen van het ontbindingsbesluit feitelijk worden vereffend (de activa worden voorafgaand aan ontbinding verzilverd en de passiva worden aangezuiverd indien mogelijk), zodat ten tijde van ontbinding geen baten meer bestaan. Wanneer het ontbindingsbesluit is genomen en hiervan, alsmede het feit dat er geen baten meer bestaan, opgave wordt gedaan aan de Kamer van Koophandel, ${ }^{6}$ houdt de rechtspersoon van rechtswege op te bestaan.

De heersende opvatting is dat turboliquideren is toegestaan wanneer er nog schulden bestaan. ${ }^{7}$ Ik heb daarom al vaker betoogd dat de turboliquidatie als ontbindingswijze een geschikte tool voor fraudeurs is geworden. ${ }^{8}$ Fraudeurs hoeven er slechts voor te zorgen dat er ten tijde van ontbinding geen baten, maar slechts schulden bestaan, en kunnen vervolgens met

4 Dit is het geval wanneer geen aan de vereffenaar bekende baten meer aanwezig zijn: art. 2:23b lid 9 jo. art. 2:19 lid 6 BW.

5 Zie ook S. Renssen, Perikelen rondom de onterechte - en soms zelfs onrechtmatige - turboliquidatie, TvOB 2021, afl. 3, p. 78-89.

6 Dit kan online via het invullen van formulier $17 \mathrm{a}$, zie 'Inschrijving ontbinding vennootschap, rechtspersoon of maatschap' (kvk.nl).

7 Zie o.a. Rb. Rotterdam 20 maart 2014, ECLI:NL:RBROT:2014:2052; Rb. Rotterdam 21 maart 2014, ECLI:NL:RBROT:2014:2548; Rb. Rotterdam 20 mei 2014, ECLI:NL:RBROT:2014:4427; Rb. Rotterdam 10 februari 2015, ECLI:NL:RBROT:2015:1570; Rb. Den Haag 10 februari 2015, ECLI:NL:RBDHA:2015:1976; Rb. Den Haag 11 maart 2015, ECLI:NL:RBDHA:2015:2569; Hof Den Haag 2 juli 2015, ECLI: NL:GHDHA:2015:1846; HR 18 december 2015, ECLI:NL:HR:2015: 3636; Rb. Gelderland 27 juni 2016, ECLI:NL:RBGEL:2016:3490, JOR 2016/268 m.nt. S. Renssen; Rb. Rotterdam 18 mei 2017, ECLI:NL: RBROT:2017:3879; Rb. Zeeland-West-Brabant 1 augustus 2018, ECLI: NL:RBZWB:2018:4728; Rb. Overijssel 9 oktober 2018, ECLI:NL: RBOVE:2018:4487.

8 Zie o.a. S. Renssen, De turboliquidatie van de besloten vennootschap (VDHI nr. 131), Deventer: Wolters Kluwer 2016; S. Renssen, Turbo liquidation of a company: An open invitation to commit fraud?, European Company Law 2016, afl. 3, p. 92-97; S. Renssen, Artikel 2:19 lid 4 BW: een maas in de wet?, JBN 2016/13, p. 3-6; S. Renssen, Reactie op 'Turboliquidatie of faillissementsaangifte bij geringe baten?', TvOB 2019, afl. 1, p. 15-17; S. Renssen, Loze beloftes en strenge rechters. De turboliquidatie in ontwikkeling, Vakblad Estate Planning 2020/64, p. 6-11; Renssen 2021, p. 78-89. 


\section{Maandblad}

Ondernemingsrecht

de noorderzon vertrekken. In het licht van deze misbruikgevoeligheid van de turboliquidatie als ontbindingswijze heeft minister Dekker uiteindelijk het conceptwetsvoorstel Tijdelijke wet transparantie turboliquidatie geschreven:

'De verwachte toename van het gebruik van ontbinding zonder baten op korte termijn draagt tevens een toename van het risico in zich van misbruik van deze regeling in het geval de rechtspersoon ophoudt te bestaan met achterlating van schulden. Het onbetaald laten van schulden kan te maken hebben met onrechtmatig of frauduleus handelen van bestuurders."

De kern van dit conceptwetsvoorstel ligt - zoals de titel al verraadt - in het verruimen van de transparantie rondom turboliquidaties voor schuldeisers. Vooralsnog bevinden onbetaald gebleven schuldeisers zich in een benarde positie wanneer een rechtspersoon verdwijnt via turboliquidatie. Een formele vereffeningsprocedure ontbreekt, terwijl schuldeisers op grond van artikel 2:24 lid $4 \mathrm{BW}$ ook geen inzage hebben in de administratie van de ontbonden rechtspersoon. Daarnaast hoeft het bestuur over het laatste verkorte boekjaar geen jaarstuk op te maken. ${ }^{10}$ Een schuldeiser zou slechts nog van artikel 2:23c lid $1 \mathrm{BW}$ gebruik kunnen maken; een via turboliquidatie verdwenen rechtspersoon kan herleven. Een schuldeiser dient alsdan echter het bestaan van een bate aan te tonen en draagt daarin de bewijslast. Hoewel het begrip bate veelal ruim wordt uitgelegd in het voordeel van de schuldeiser, ${ }^{11}$ blijft het vaak lastig om zelfs een potentiële bate aan te tonen. De schuldeiser heeft immers geen zicht op wat zich binnen de vennootschap heeft afgespeeld tijdens de feitelijke vereffening. Het conceptwetsvoorstel introduceert daarom een verantwoordingsen bekendmakingsverplichting voor het bestuur. Er dient een aantal stukken openbaar te worden gemaakt in het geval van turboliquidatie, terwijl de aan het bestuur bekende schuldeisers hiervan op de hoogte dienen te worden gebracht.

Hoewel het mij deugd doet dat de overheid de noodzaak inziet van aanpassing van de huidige regelgeving rondom turboliquidaties, vraag ik mij af of de Tijdelijke wet transparantie turboliquidatie zoals voorgesteld het gewenste effect gaat hebben. In

9 Concept-MvT Tijdelijke wet transparantie turboliquidatie (hierna: concept-MvT), p. 1, te downloaden via: Overheid.nl, Consultatie Tijdelijke wet transparantie turboliquidatie (internetconsultatie.nl).

10 Zie hierover uitgebreid: S. Renssen, De problematiek rondom de ontbrekende jaarrekening bij turboliquidatie, TvJ 2016, afl. 2, p. 47-52 (hierna: Renssen 2016a).

11 Zie bijv. HR 11 oktober 1991, ECLI:NL:HR:1991:ZC0366, NJ 1992/132. Zie ook de conclusie van A-G Timmerman, ECLI:NL:PHR: 2004:AO2779, bij HR 26 maart 2004, NJ 2004/330. Zie ook in het kader van heropening via een faillissementsaanvraag: Hof 's-Gravenhage 6 september 2012, ECLI:NL:GHSGR:2012:BX7085, JOR 2013/217 m.nt. Nethe; Hof Den Haag 2 juli 2015, ECLI:NL:GHDHA:2015: 1846, JOR 2016/46 m.nt. Renssen. Zie anders bijv.: Rb. Midden-Nederland 11 juni 2015, ECLI:NL:RBMNE:2015:4479; Hof Amsterdam 31 maart 2011, ECLI:NL:GHAMS:2011:BQ1156; Rb. Zeeland-WestBrabant 1 augustus 2018, ECLI:NL:RBZWB:2018:472, JOR 2019/31 m.nt. Renssen. deze bijdrage zal ik dan ook een aantal kritische noten belichten en betogen dat het een doekje voor het bloeden van de schuldeisers is. In paragraaf 2 zet ik het conceptwetsvoorstel uiteen. Mijn kritische kanttekeningen vangen aan in paragraaf 3. In paragraaf 4 zet ik uiteen hoe dan verder te gaan met de turboliquidatie. De bijdrage wordt afgesloten in paragraaf 5 .

\section{De Tijdelijke wet transparantie turboliquidatie}

Over het fenomeen turboliquidatie is de afgelopen jaren veel geschreven en de aandacht die hieraan wordt besteed in de media is groeiende. ${ }^{12}$ Uiteindelijk heeft de overheid het onderwerp ook opgepakt: Kamerlid Van Oosten vroeg op 4 oktober2018 tijdens een overleg van de vaste commissie voor Justitie en Veiligheid met minister Dekker en minister Grapperhaus in het kader van bestrijding van (faillissements)fraude aandacht voor turboliquidaties. ${ }^{13}$ Volgens hem verdient artikel 2:19 lid 4 BW zodanige aanpassing dat turboliquidatie niet mogelijk is indien er nog schulden bestaan. In 2018 gaf minister Dekker naar aanleiding van de vragen gesteld door Van Oosten aan het fenomeen van de turboliquidatie nader te bestuderen, hetgeen - met als basis de onderzoeksresultaten inzake turboliquidaties over de periode 2010-2016 voorbereid door de Belastingdienst - uiteindelijk geresulteerd heeft in een Kamerbrief waarin de minister belooft een wetsvoorstel voor te bereiden. ${ }^{14}$ Daarin geeft hij aan niet zo ver te willen gaan als Van Oosten en dus niet voornemens te zijn te bewerkstelligen dat turboliquidatie slechts kan plaatsvinden wanneer baten én schulden ontbreken. De minister acht het van belang dat rechtspersonen eenvoudig kunnen worden opgericht en dat deze ook weer eenvoudig zijn op te heffen indien de activiteiten worden gestaakt. De minister richt zich op een verbetering van de positie van schuldeisers die onbetaald achterblijven na toepassing van de turboliquidatie. Op 28 juni 2021 wordt eindelijk het conceptwetsvoorstel voor internetconsultatie aangeboden, zij het in een iets ander jasje gegoten: de Tijdelijke wet transparantie turboliquidatie. ${ }^{15}$

De Tijdelijke wet transparantie turboliquidatie beoogt volgens de conceptmemorie van toelichting de transparantie van de regeling omtrent de turboliquidatie te vergroten, de rechtsbescherming van schuldeisers te verbeteren en misbruik ervan effectiever te bestrijden. ${ }^{16}$ Volgens de minister zal hierdoor ook het vertrouwen in de turboliquidatie als ontbindingswijze worden vergroot, waardoor de regeling toegankelijker wordt voor ondernemingen en het gebruik daarvan wordt gefacili-

12 Zie bijv. V. van der Boon \& S. Eikelenboom, Actie tegen nieuwe fraudevorm met 'plof-bv's', Het Financieele Dagblad 2016/212; B. Mos, Schrikbarende groei van turboliquidaties, De Telegraaf 18 augustus 2018; C. Driessen, Turboliquidatie van BV's. Een 'prachtige toolkit' voor fraudeurs, NRC Next 20 november 2018; J. Polman, Maatregelen tegen fraude met plof-bv's op komst, Het Financieele Dagblad 2019/239.

13 Kamerstukken II 2018/19, 29911, nr. 210, p. 19

14 Kamerstukken II 2019/20, 29911, nr. 253.

15 Zie Overheid.nl, Consultatie Tijdelijke wet transparantie turboliquidatie (internetconsultatie.nl).

16 Concept-MvT, p. 2. 


\section{Maandblad}

Ondernemingsrecht

teerd. Met een gecontroleerde beëindiging van rechtspersonen via turboliquidatie kan worden voorkomen dat schulden oplopen en een faillissement onafwendbaar wordt, aldus minister Dekker. De voorgestelde regeling zorgt er volgens hem voor dat ondernemers, als de economische gevolgen van de COVID-19-pandemie straks zijn bedwongen, zowel privé als zakelijk verder kunnen. Hieronder zullen de verschillende onderdelen van het conceptwetsvoorstel - voor zover relevant voor deze bijdrage - achtereenvolgens worden besproken.

\subsection{De verantwoordings-en bekendmakingsverplichting}

Voorgesteld wordt artikel 2:19b BW in het leven te roepen, op grond waarvan het bestuur in geval van toepassing van turboliquidatie een verantwoordings- en bekendmakingsverplichting krijgt. Wanneer een rechtspersoon wordt ontbonden via artikel 2:19 lid 1 onder a BW (via een aandeelhoudersbesluit of indien het een stichting betreft; een bestuursbesluit) en gelet op artikel 2:19 lid 4 BW direct ophoudt te bestaan (turboliquidatie), dient het bestuur op grond van de nieuwe regeling binnen tien werkdagen na de ontbinding aan het handelsregister alwaar de rechtspersoon is ingeschreven de volgende stukken te deponeren:

a. een balans en staat van baten en lasten met betrekking tot het boekjaar waarin de rechtspersoon is ontbonden;

b. een schriftelijke opgave van redenen voor het ontbreken van baten op het tijdstip van ontbinding en, indien van toepassing, het onbetaald laten van schuldeisers;

c. een slotuitdelingslijst, indien voorafgaand aan de ontbinding van de rechtspersoon schuldeisers zijn voldaan in het kader van de afwikkeling van het vermogen van de rechtspersoon. De lijst vermeldt de totale bevoorrechte schuldeisers, door pand, hypotheek of retentierecht gedekte vorderingen, concurrente vorderingen, alsmede de daarop ontvangen uitkeringen en hetgeen na voldoening van de schuldeisers van het vermogen overgebleven is; en

d. de jaarrekeningen inzake de boekjaren die voorafgaan aan het boekjaar waarin de rechtspersoon is ontbonden, indien daarvoor op grond van Boek $2 \mathrm{BW}$ een plicht bestaat waar nog niet aan is voldaan, in voorkomend geval inclusief de accountantsverklaring als bedoeld in artikel 2:393 lid 5 BW.

Het gaat om stukken waarin het bestuur financiële verantwoording aflegt over de toegepaste turboliquidatie en de eventuele feitelijke vereffening die daaraan vooraf is gegaan. ${ }^{17} \mathrm{De}$ stukken zullen aldus de minister in het handelsregister zijn in te zien, zolang de verplichte bewaartermijnen gelden. De opgave van de ontbinding wordt permanent bewaard, terwijl de gedeponeerde stukken zeven jaar zullen worden bewaard. Niet-nakoming van deze verantwoordingsplicht wordt op grond van het voorgestelde artikel II van de Tijdelijke wet transparantie turboliquidatie strafbaar gesteld in de Wet op de economische delicten (WED) (met een maximumstraf van zes maanden hechtenis en geldboete van de vierde categorie).

17 Concept-MvT, p. 7-8.
Op grond van artikel 2:19b lid 2 BW dient het bestuur onverwijld nadat bovenvermelde stukken zijn gedeponeerd daarvan mededeling te doen aan de schuldeisers van de rechtspersoon die verdwijnt via turboliquidatie, tenzij het bestuur niet over de gegevens beschikt die daarvoor nodig zijn. Het gaat er volgens de minister om dat de schuldeisers spoedig kennis kunnen nemen van de ontbinding en de mogelijkheid om de gedeponeerde stukken te raadplegen. ${ }^{18}$ Daaraan wordt in de conceptmemorie van toelichting toegevoegd dat het niet de bedoeling is een plicht in het leven te roepen voor het bestuur om onderzoek te doen naar de contactgegevens van schuldeisers en evenmin naar de juistheid daarvan. Van schuldeisers mag redelijkerwijs worden verwacht dat zij ervoor zorg dragen dat de schuldenaar, zijnde de rechtspersoon, over hun accurate gegevens beschikt, aldus de minister. Terwijl het niet voldoen aan het eerste lid van artikel 2:19b BW strafbaar is gesteld in de WED, is dit niet het geval voor schending van het tweede lid. In paragraaf 2.2 zal bovendien duidelijk worden dat ook het voorgestelde bestuursverbod van artikel 2:19c BW niet kan worden ingeroepen in geval van schending van de bekendmakingsverplichting. Met andere woorden: schending van het voorgestelde tweede lid van artikel 2:19c BW lijkt geen consequenties te hebben voor het bestuur van de via turboliquidatie verdwenen rechtspersoon.

Het voordeel van de voorgestelde verantwoordings- en bekendmakingsverplichting is - zo wordt betoogd in de concepttoelichting - dat terwijl de snelle en efficiënte wijze van ontbinding via turboliquidatie wordt behouden, de rechtsbescherming van schuldeisers verbetert. ${ }^{19}$ Laatstgenoemden kunnen zich door raadpleging van de gedeponeerde stukken een beter beeld vormen van de financiële situatie van de verdwenen rechtspersoon. Op grond daarvan zijn zij beter in staat om in te schatten of zich onregelmatigheden hebben voorgedaan in het zicht van ontbinding en er wellicht een grond is voor bestuurdersaansprakelijkheid. De bewijslast in een procedure ex artikel 2:23c lid $1 \mathrm{BW}$ - waarin de schuldeiser het bestaan van een bate dient aan te tonen - lijkt daarmee te worden vereenvoudigd.

\subsection{Het bestuursverbod}

$\mathrm{Na}$ artikel 2:19b BW wordt voorgesteld artikel 2:19c BW in te voeren. Hiermee wordt het civielrechtelijke bestuursverbod buiten faillissementsrechtelijke context uitgebreid. ${ }^{20}$ Wanneer een rechtspersoon is ontbonden via artikel 2:19 lid 1 onder a of e BW (via een aandeelhoudersbesluit of indien het een stichting betreft, een bestuursbesluit respectievelijk via een beschikking van de Kamer van Koophandel ex art. 2:19a BW) en gelet op artikel 2:19 lid $4 \mathrm{BW}$ direct ophoudt te bestaan (turboliquidatie), terwijl één of meer schuldeisers geheel of gedeeltelijk onbetaald zijn gebleven, dan kan de rechtbank op ver-

18 Concept-MvT, p. 8.

19 Concept-MvT, p. 8.

20 Voor het bestuur van een stichting bestaat het civielrechtelijk bestuursverbod al in art. 2:298 lid $3 \mathrm{BW}$ in geval van ontslag door de rechtbank. 


\section{Maandblad}

Ondernemingsrecht

zoek van het Openbaar Ministerie een bestuursverbod opleggen aan de (gewezen) bestuurder, indien:

a. de bestuurder in geval van een ontbinding ex artikel 2:19 lid 1 onder a BW niet heeft voldaan aan de verantwoordingsverplichting van artikel 2:19b lid $1 \mathrm{BW}$; of

b. de bestuurder doelbewust namens de rechtspersoon handelingen heeft verricht of nagelaten, waardoor één of meer schuldeisers aanmerkelijk zijn benadeeld; ${ }^{21}$ of

c. in de twee daaraan voorafgaande jaren de bestuurder, hetzij als zodanig, hetzij als natuurlijk persoon handelend in de uitoefening van een beroep of bedrijf, ten minste tweemaal eerder betrokken was bij een beëindiging van een rechtspersoon op een wijze als bedoeld in artikel $2: 19 \mathrm{~b}$ lid $1 \mathrm{BW}$, waarbij één of meer schuldeisers geheel of gedeeltelijk onbetaald zijn gebleven, tenzij hem daarvan geen persoonlijk verwijt treft.

De gedachte achter dit voorgestelde bestuursverbod is volgens de minister het bestrijden van malafide turboliquidaties. ${ }^{22}$ In het tweede lid van artikel 2:19c BW is een schakelbepaling naar artikel 106b (behalve het vijfde lid, waarmee de mogelijkheid tot het opleggen van een dwangsom buiten toepassing wordt verklaard), ${ }^{23} 106 \mathrm{c}$ en $106 \mathrm{~d} \mathrm{Fw}$ opgenomen. In de artikelen $106 \mathrm{~b}$ en $106 \mathrm{c}$ Fw zijn de gevolgen van een opgelegd bestuursverbod opgenomen. De bestuurder aan wie een bestuursverbod is opgelegd, kan ingevolge artikel 106b lid $1 \mathrm{Fw}$ gedurende de periode waarvoor het verbod is opgelegd (maximaal vijf jaar) niet tot bestuurder of commissaris van een rechtspersoon worden benoemd. Een benoeming tot bestuurder of commissaris in weerwil van een onherroepelijk opgelegd bestuursverbod is nietig. In beginsel vormt het bestuursverbod bovendien een beletsel voor de uitoefening van zijn functie als bestuurder of commissaris bij alle andere rechtspersonen. Deze rechtspersonen worden door de rechtbank in de gelegenheid gesteld om hun zienswijze over het gevraagde bestuursverbod en de mogelijke gevolgen daarvan naar voren te brengen. De rechtbank kan gedurende de procedure de desbetreffende bestuurder of commissaris op verzoek van het Openbaar Ministerie schorsen en zo nodig voorzien in de tijdelijke aanstelling van één of meer bestuurders of commissarissen, aldus artikel 106c lid 3 en 4 Fw. Een opgelegd bestuursverbod wordt geregistreerd bij het handelsregister, welke registratie volledig openbaar en voor iedereen raadpleegbaar is. ${ }^{24}$ Volgens artikel 106b lid 6 Fw kan een uitspraak houdende oplegging van een bestuursverbod niet uitvoerbaar bij voorbaat worden verklaard.

21 De term 'doelbewust' sluit aan bij art. 106a lid 1 sub b Fw en benadrukt het intentionele karakter van de benadeling.

22 Concept-MvT, p. 10.

23 Dit betreft de bepaling dat een dwangsom kan worden opgelegd ter verzekering van de naleving van het bestuursverbod, en die dwangsom komt dan ten goede van de boedel of van de Staat. De reguliere mogelijkheden van art. 611a e.v. Rv voor de rechter om een dwangsom op te leggen worden voldoende geacht.

24 Zie Stb. 2019, 280.
Voor de toepassing van artikel 106a-106c Fw wordt ingevolge artikel 106d lid 1 Fw als bestuurder tevens aangemerkt degene die het beleid van de rechtspersoon heeft bepaald of mede heeft bepaald als ware hij bestuurder. Ook wordt ingevolge artikel 106d lid 2 Fw met de bestuurder gelijkgesteld de uitvoerend bestuurder en met de commissaris de niet-uitvoerend bestuurder, indien de bestuurstaken zijn verdeeld over uitvoerende en niet-uitvoerende bestuurders (het one-tier boardmodel).

Het derde lid van artikel 2:19c BW bepaalt vervolgens dat geen bestuursverbod kan worden opgelegd indien het overlijden van de bestuurder een omstandigheid is op grond waarvan de rechtspersoon door een beschikking van de Kamer van Koophandel is ontbonden.

\subsection{Tijdelijk karakter}

Artikel IV van het conceptwetsvoorstel bepaalt dat de verantwoordings- en bekendmakingsverplichting (art. 2:19b BW) alsmede de voorgestelde regeling omtrent het bestuursverbod (art. 2:19c BW) vervallen. Artikel IV treedt volgens artikel V twee jaar na het tijdstip van inwerkingtreding van de Tijdelijke wet transparantie turboliquidatie in werking. De keuze van de minister voor het tijdelijke karakter van de wet lijkt overwegend van financiële aard te zijn. De minister verwacht dat de uitbraak van de COVID-19-pandemie onder meer tot gevolg zal hebben dat meer ondernemers gebruik zullen willen maken van de turboliquidatie als ontbindingsmogelijkheid. ${ }^{25} \mathrm{Ge}-$ let hierop heeft het demissionaire kabinet een bijzonder budget beschikbaar kunnen maken als onderdeel van een steun- en herstelpakket in het kader van de COVID-19-pandemie. Het budget is volgens de minister nodig, nu de invoering van de voorgestelde maatregelen overheidsuitgaven met zich zal brengen. Het gaat daarbij volgens de concepttoelichting om deponering van stukken bij het handelsregister, dat wordt beheerd door de Kamer van Koophandel, alsmede kosten om de deponeringsverplichting strafrechtelijk te kunnen handhaven. Het budget dat is vrijgemaakt voor onderhavig conceptwetsvoorstel is slechts beschikbaar voor twee jaar, omdat de verwachting is dat vanaf dat moment geen sprake meer zal zijn van directe economische effecten als gevolg van de uitbraak van COVID-19. Het is ook daarom dat wordt voorgesteld de wet een tijdelijk karakter van in beginsel twee jaar te geven.

Wel biedt het conceptwetsvoorstel in artikel V lid 3 de mogelijkheid om de werkingsduur van de wet bij koninklijk besluit te verlengen. Desondanks blijft de wet in de regel een tijdelijk karakter hebben; het nieuwe tijdstip van vervallen van de wet in geval van verlenging mag steeds ten hoogste twee maanden na het tijdstip waarop de wet zou vervallen, liggen. De minister geeft daarbij aan dat het na afloop van de genoemde periode van twee jaar wenselijk kan blijken om de voorgestelde maatregelen structureel in te voeren. Het ligt daarbij in de rede om een toekomstig kabinet de ruimte te geven om hierover te

25 Concept-MvT, p. 2-3. 


\section{Maandblad}

Ondernemingsrecht

beslissen. Daarom zal de effectiviteit van de maatregelen worden gemonitord, aldus de minister. Mocht blijken dat een structurele invoering van de maatregelen gewenst is, dan is een wetswijziging nodig, waarbij in de tussentijd telkens de nu in te voeren maatregelen kunnen worden verlengd.

\section{Kritische kanttekeningen}

Een van mijn bedenkingen bij het voorstel ziet op het tijdelijk karakter van de wet. Zoals reeds in de inleiding van deze bijdrage aangehaald, ving het proces dat uiteindelijk resulteerde in onderhavig conceptwetsvoorstel geruime tijd voordat de COVID-19-pandemie uitbrak aan. Het is dan ook op zijn minst eigenaardig te noemen dat het uiteindelijke conceptwetsvoorstel wordt gelinkt aan de COVID-19-pandemie en daardoor ook een tijdelijk karakter draagt, zeker gelet op het doel van het conceptwetsvoorstel: het vergroten van de transparantie rondom turboliquidaties, het verbeteren van de rechtsbescherming van schuldeisers en een effectievere bestrijding van misbruik. ${ }^{26}$ Gelet op het hoge aantal turboliquidaties in de praktijk kan moeilijk worden gesteld dat het bereiken van voornoemde doelstellingen slechts in tijden van een pandemie van belang is. Neem als voorbeeld het jaar 2018. In dat jaar verdwenen bijna 33.000 van de iets minder dan 37.000 (89\%) ontbonden vennootschappen via turboliquidatie. ${ }^{27}$ In datzelfde jaar werden slechts 3144 bedrijven en instellingen failliet verklaard. ${ }^{28}$ Uit het onderzoek van de Belastingdienst is bovendien gebleken dat in ongeveer $80 \%$ van de toegepaste turboliquidaties geen fiscale schulden bestaan. In absolute cijfers vertaald betekent dit - toegepast op de cijfers van 2018 dat bij 6600 vennootschappen die via turboliquidatie verdwenen nog fiscale schulden bestonden. Dit is ruim het dubbele van het totaal aantal faillissementen in dat jaar (3144). Daar zitten de gevallen waarin geen fiscale schulden, maar wel andersoortige schulden bestonden niet eens bij. Ik ben het met minister Dekker eens dat het bestaan van schulden ten tijde van turboliquidatie niet altijd betekent dat er misbruik van de regeling wordt gemaakt of dat er fraude wordt gepleegd, maar deze cijfers zijn in mijn ogen toch schrikbarend en laten zien dat het treffen van waarborgen voor schuldeisersbescherming belangrijk is, ook buiten een pandemiesituatie. Ik hoop dan ook van harte dat het toekomstige kabinet zal komen met een wetsvoorstel van permanente aard inzake transparantie rondom turboliquidaties.

\subsection{De verantwoordings-en bekendmakingsverplichting: een doekje voor het bloeden?}

Voorgesteld wordt om artikel 2:19b BW in het leven te roepen, op grond waarvan het bestuur binnen tien werkdagen na turboliquidatie bij het handelsregister stukken dient te deponeren waarin het bestuur financiële verantwoording aflegt over de toegepaste turboliquidatie en de eventuele voorafgaan-

26 Concept-MvT, p. 2.

27 Kamerbrief over voorgenomen wetswijziging Turboliquidatie van rechtspersonen d.d. 7 oktober 2019

28 Zie CBS, In 2018 laagste aantal faillissementen sinds 2001 (cbs.nl). de feitelijke vereffening. ${ }^{29}$ Het tweede lid van artikel 2:19b BW omvat de bekendmakingsverplichting: het bestuur dient onverwijld nadat de stukken als bedoeld in het eerste lid zijn gedeponeerd daarvan mededeling te doen aan de schuldeisers, tenzij het bestuur niet over de gegevens beschikt die daarvoor nodig zijn. De vraag is of de beoogde doelstelling - verbetering van de positie van de achterblijvende schuldeisers en het effectiever bestrijden van misbruik - met deze voorgestelde bepaling kan worden bereikt. Buiten kijf staat dat het een stap in de goede richting is wat betreft transparantievergroting naar schuldeisers toe, maar ik betwijfel of misbruik van en fraude met turboliquidaties hierdoor effectiever worden bestreden. Een vennootschap zal nog steeds kunnen verdwijnen via turboliquidatie, terwijl schuldeisers onbetaald achterblijven. Van de nieuw voorgestelde vorm van de turboliquidatie kunnen fraudeurs nog altijd eenvoudig misbruik maken; een misleidende slotbalans en bestuursverslag in de zin van artikel 2:19b BW lijken al voldoende. Wanneer uit de door het bestuur op te maken stukken ex artikel 2:19b lid $1 \mathrm{BW}$ immers niet valt op te maken wat er binnen de rechtspersoon voorafgaand aan ontbinding heeft plaatsgevonden, dan zijn schuldeisers met deze bepaling niet geholpen.

Ook de wetgever zelf lijkt ervan uit te gaan dat het bestaan van misleidende jaarrekeningen en bestuursverslagen wel degelijk denkbaar is. Reeds in artikel $49 \mathrm{~b}$ van het Wetboek van Koophandel van 1929 was bepaald dat wanneer in de balans, winst-en-verliesrekening en toelichting een misleidende voorstelling werd gegeven van de toestand van de vennootschap, bestuurders hoofdelijk aansprakelijk waren tegenover derden voor de schade die dezen dientengevolge lijden. Deze grond voor bestuurdersaansprakelijkheid is thans vastgelegd in artikel 2:139/249 BW. Op grond hiervan geldt dat bestuurders tegenover derden hoofdelijk aansprakelijk zijn indien door de jaarrekening, door tussentijdse cijfers die de vennootschap bekend heeft gemaakt of door het bestuursverslag een misleidende voorstelling wordt gegeven van de toestand van de vennootschap. De aansprakelijkheid strekt zich uit tot schade die derden door de misleidende voorstellen hebben geleden, waarbij geldt dat een bestuur dat bewijst dat dit niet aan hen te wijten is, niet aansprakelijk is.

Het geven van een misleidende voorstelling van de toestand van de vennootschap in de stukken genoemd in het voorgestelde artikel 2:19a lid 1 onder a, b en c BW kan niet leiden tot bestuurdersaansprakelijkheid op grond van artikel 2:139/249 BW. De stukken aldaar genoemd ${ }^{30}$ vallen niet onder de reikwijdte van artikel 2:139/249 BW. Het gaat in voormelde bepalingen om een misleidende voorstelling in de jaarreke-

29 Concept-MvT, p. 7-8.

30 Zijnde (a) een balans en staat van baten en lasten met betrekking tot het boekjaar waarin de rechtspersoon is ontbonden, (b) een schriftelijke opgave van redenen voor het ontbreken van baten op het tijdstip van ontbinding en, indien van toepassing, het onbetaald laten van schuldeisers en (c) een slotuitdelingslijst indien voorafgaand aan de ontbinding van de rechtspersoon schuldeisers zijn voldaan in het kader van de afwikkeling van het vermogen van de rechtspersoon. 


\section{Maandblad}

Ondernemingsrecht

ning, tussentijdse cijfers (waarmee wordt gedoeld op art. 2:105 lid 4 BW; een tussentijdse balans in het kader van een dividenduitkering) en het bestuursverslag ex artikel 2:391 BW. ${ }^{31}$ Hoewel een balans als bedoeld in artikel 2:19a lid 1 onder a BW gelet op artikel 2:361 BW onderdeel uitmaakt van de jaarrekening, kan niet worden gesteld dat een dergelijke balans daarmee onder de reikwijdte van artikel 2:139/249 BW komt te vallen. Over het laatste verkorte boekjaar in geval van turboliquidatie hoeft geen volledige jaarrekening als bedoeld in artikel 2:361 BW (en in art. 2:139/249 BW) te worden opgemakkt. $^{32}$

Heeft de wetgever de (thans ontbrekende) link met artikel 2:139/249 BW over het hoofd gezien? Of acht de wetgever het minder belangrijk wanneer in de stukken genoemd in artikel 2:19b BW een misleidende voorstelling wordt gegeven? Of wordt ervan uitgegaan dat met de in het leven te roepen verantwoordingsplicht geen misleidende voorstellingen meer worden gegeven? Wanneer men kijkt naar de stukken genoemd in artikel 2:19b BW, dan lijken het mij juist de stukken genoemd in onderdeel a, b en c (die niet onder de reikwijdte van art. 2:139/249 BW vallen) te zijn die voor schuldeisers van groot belang zijn wanneer zij voor een procedure tot herleving van de vennootschap willen gaan (art. 2:23c lid $1 \mathrm{BW}$ ). Het lijkt mij dat uit de jaarrekeningen over de voorafgaande boekjaren (onderdeel $\mathrm{d}$ ) de minst nuttige informatie valt te halen voor schuldeisers in het kader van het aantonen van een bate in de zin van artikel 2:23c lid 1 BW. Overigens zal op grond van het voorgestelde artikel 2:19c BW in geval van het niet voldoen aan de verantwoordingsplicht van artikel 2:19b lid 1 BW wel een bestuursverbod kunnen worden opgelegd. Hierop zal in paragraaf 3.2 verder worden ingegaan.

\subsection{Het bestuursverbod: een lege buls}

Met het voorgestelde artikel 2:19c BW krijgt het Openbaar Ministerie de bevoegdheid om een bestuursverbod in geval van turboliquidatie te verzoeken aan de rechtbank.

Volgens de minister is het civielrechtelijk bestuursverbod van artikel 106a e.v. Fw 'een beproefd instrument gebleken voor bestuurders die zich - kort gezegd - bezighouden met faillissementsfraude of faillissementsrecidive of die zich schuldig hebben gemaakt aan wanbestuur in de aanloop naar een faillissement'. ${ }^{33}$ Het civielrechtelijk bestuursverbod van artikel $106 \mathrm{a}$ e.v. Fw is per 1 juli 2016 in werking getreden. ${ }^{34}$ In de periode 1 juli 2016 tot en met 1 september 2021 zijn in totaal slechts

\footnotetext{
31 Asser/Kroeze 2-I 2021/573.

32 Zie uitgebreid Renssen 2016a.

33 Concept-MvT, p. 10.

34 Stb. 2016, 153.
}

tien civielrechtelijke bestuursverboden opgelegd. ${ }^{35}$ Vijf van de tien bestuursverboden zijn verzocht door het Openbaar Ministerie. ${ }^{36}$ Dat lijken mij relatief weinig bestuursverboden ten opzichte van het aantal faillissementen dat wordt uitgesproken. Of gesproken kan worden van een beproefd instrument, valt sterk te betwijfelen. ${ }^{37}$ Het civielrechtelijk bestuursverbod zou vijf jaar na inwerkingtreding (dit jaar) worden geëvalueerd, ${ }^{38}$ maar tot op heden zijn hiervan geen resultaten bekend. De vraag rijst dan ook hoe vaak het Openbaar Ministerie gebruik zal gaan maken van het bestuursverbod als bedoeld in artikel 2:19c BW. Of het bestuursverbod een preventieve werking in misbruikbestrijding rondom turboliquidaties zal hebben, lijkt mij ook twijfelachtig, wanneer de verwachting is dat het Openbaar Ministerie toch niet vaak gebruik zal maken van de mogelijkheid een bestuursverbod te verzoeken. Ik zou in dit kader in overweging willen meegeven schuldeisers ook de bevoegdheid te geven een bestuursverbod te verzoeken; dat zorgt er mijns inziens voor dat artikel 2:19c BW geen lege huls blijft. Het lijkt mij dat een schuldeiser (die onbetaald is achtergebleven na een toegepaste turboliquidatie) die via bestuurdersaansprakelijkheid en/of de weg van artikel 2:23c lid $1 \mathrm{BW}$ via de rechtbank probeert alsnog zijn vordering betaald te krijgen, eerder gemotiveerd is om daarbij een bestuursverbod te verzoeken indien een van de omstandigheden zoals genoemd in artikel 2:19c lid 1 BW zich voordoet, dan het Openbaar Ministerie.

\section{Het juiste pad: onderzoek naar de turboliquidatie in de praktijk}

De minister geeft in de conceptmemorie van toelichting - mijns inziens terecht - aan dat vaststaat dat malafide turboliquidaties zich voordoen. ${ }^{39}$ De minister vervolgt dat het evenwel niet eenvoudig is de omvang hiervan vast te stellen, omdat onregelmatigheden voorafgaand aan de ontbinding plaatsvinden en derden (thans) niet zonder meer beschikken over de financiële gegevens van de via turboliquidatie verdwenen rechtspersoon. Omdat het conceptwetsvoorstel meer transparantie biedt naar schuldeisers toe wat betreft de financiële situ-

35 Rb. Overijssel 1 september 2021, ECLI:NL:RBOVE:2021:3449; Rb. Overijssel 31 december 2020, ECLI:NL:RBOVE:2020:4617; Hof Amsterdam 10 november 2020, ECLI:NL:GHAMS:2020:3092; Rb. Overijssel 8 april 2020, ECLI:NL:RBOVE:2020:1557; Rb. Gelderland 18 maart 2020, ECLI:NL:RBGEL:2020:1882; Rb. Limburg 24 december 2019, ECLI:NL:RBLIM:2019:11562; Rb. Overijssel 20 juni 2019, ECLI:NL:RBOVE:2019:2836; Rb. Midden-Nederland 19 december 2018, ECLI:NL:RBMNE:2018:6261; Rb. Rotterdam 14 november 2018, ECLI:NL:RBROT:2018:9777; Rb. Den Haag 13 juni 2018, ECLI:NL:RBDHA:2018:8801.

36 Rb. Overijssel 31 december 2020, ECLI:NL:RBOVE:2020:4617; Hof Amsterdam 10 november 2020, ECLI:NL:GHAMS:2020:3092; Rb. Gelderland 18 maart 2020, ECLI:NL:RBGEL:2020:1882; Rb. Overijssel 20 juni 2019, ECLI:NL:RBOVE:2019:2836; Rb. Midden-Nederland 19 december 2018, ECLI:NL:RBMNE:2018:6261.

37 Zie bijv. ook de reactie van de Gecombineerde Commissie Vennootschapsrecht op het conceptwetsvoorstel, p. 7 en de reactie van de Raad voor de rechtspraak, p. 4, te downloaden via: Overheid.nl, Consultatie Tijdelijke wet transparantie turboliquidatie (internetconsultatie.nl).

38 Aanhangsel Handelingen II 2017/18, nr. 1665

39 Concept-MvT, p. 5. 


\section{Maandblad}

Ondernemingsrecht

atie van de rechtspersoon voorafgaand aan turboliquidatie, lijkt hieruit te volgen dat de omvang van de maatschappelijke schade die wordt geleden door malafide/frauduleuze turboliquidaties na invoering van het conceptwetsvoorstel eenvoudiger vast te stellen zou moeten zijn. Daarnaast dient de transparantievergroting bij te dragen aan een effectievere bestrijding van misbruik van turboliquidaties. ${ }^{40} \mathrm{Ik}$ betwijfel echter of het daadwerkelijke fraudeprobleem rondom turboliquidaties hiermee wordt opgelost. Een vennootschap zal nog steeds kunnen verdwijnen via turboliquidatie, terwijl schuldeisers onbetaald achterblijven. Van de nieuw voorgestelde vorm van de turboliquidatie kunnen fraudeurs immers nog altijd relatief eenvoudig misbruik maken; een misleidende slotbalans en toelichting waarom baten ontbreken, lijken al voldoende.

De enige waterdichte manier om te bewerkstelligen dat turboliquidaties niet meer frauduleus kunnen worden gebruikt en schuldeisers daardoor kunnen worden benadeeld, lijkt een 'eenvoudige' wetswijziging van artikel 2:19 lid $4 \mathrm{BW}$ te zijn. ${ }^{41}$ Wanneer een turboliquidatie slechts mag worden toegepast wanneer een rechtspersoon over baten noch schulden aan derden beschikt, wordt in ieder geval voorkomen dat fraudeurs met de noorderzon kunnen vertrekken. De eenvoud van een dergelijke wetswijziging is echter ogenschijnlijk. Wanneer artikel 2:19 lid 4 BW op deze wijze wordt aangepast, dient tegelijkertijd de heersende legeboedelproblematiek te worden opgelost. In Nederland wordt de meerderheid van faillissementen opgeheven wegens gebrek aan baten, oftewel een lege boedel. ${ }^{42}$ Zou dit niet gebeuren, dan heeft een rechtspersoon met slechts schulden geen enkele mogelijkheid meer. Hij mag niet worden ontbonden via turboliquidatie. Wanneer die rechtspersoon aangifte tot eigen faillietverklaring doet, levert dat vanwege de onevenredigheid tussen de belangen van de aanvrager enerzijds en die van de curator anderzijds misbruik van bevoegdheid op en wordt het faillissement in lijn met het arrest van de Hoge Raad uit 2015 hoogstwaarschijnlijk vernietigd. ${ }^{43}$ Gaat men voor de reguliere ontbinding, dan zal de vereffenaar op grond van artikel 2:23a lid $4 \mathrm{BW}$ aangifte tot eigen faillietverklaring moeten doen, tenzij alle bekende schuldeisers desgevraagd instemmen met voortzetting van de vereffening van faillissement.

De turboliquidatie als ontbindingswijze wordt (hopelijk) lang niet in alle gevallen frauduleus ingezet. Het voordeel van artikel 2:19 lid $4 \mathrm{BW}$ is gelegen in het feit dat rechtspersonen die leeg zijn, eenvoudig, snel en goedkoop kunnen verdwijnen. Wanneer artikel 2:19 lid 4 BW zodanig wordt angepast dat rechtspersonen met schulden hier geen gebruik meer van mogen maken, maar via faillissement (of reguliere ontbinding in-

40 Concept-MvT, p. 2.

41 Zie ook Renssen 2019, p. 15-17; S. Renssen, Kernaanbevelingen inzake de turboliquidatie van de besloten vennootschap, TvOB 2016, afl. 5, p. 138-144.

$42 Z$ Zie uitgebreid $S$. Renssen, Het verzet van een curator in geval van een lege boedel, $\mathrm{MvO}$ 2016, afl. 1-2, p. 23-30.

43 HR 18 december 2015, ECLI:NL:HR:2015:3636. dien alle bekende schuldeisers desgevraagd instemmen met voortzetting van de vereffening van faillissement) dienen te worden geliquideerd, belast dat de rechterlijke macht (vanwege de verwachte stijging in het aantal faillissementsaanvragen) en wordt de curator met het probleem opgezadeld (tenzij de legeboedelproblematiek wordt opgelost). Het is mijns inziens juist vanwege de gevolgen die aanpassing van artikel 2:19 lid 4 BW met zich brengt van belang om gedegen onderzoek te doen naar de omvang en aard van de schade die de maatschappij lijdt als gevolg van frauduleuze turboliquidaties. ${ }^{44}$ Met die informatie kan worden gezocht naar (effectieve) oplossingen om frauduleuze turboliquidaties zo veel als mogelijk te voorkomen.

\section{Afsluitend}

Hoewel de wetgever ten tijde van het in het leven roepen van artikel 2:19 lid $4 \mathrm{BW}$ geen noodzaak zag om uitgebreid op het fenomeen van turboliquidatie in te gaan, wordt deze snelle en eenvoudige ontbindingswijze thans veelvuldig toegepast in de praktijk. Ook in de media wordt de afgelopen jaren aandacht besteed aan het fenomeen en dan met name in het kader van fraude. De turboliquidatie als ontbindingswijze lijkt een geschikte tool voor fraudeurs te zijn geworden, doordat de heersende opvatting is dat turboliquideren is toegestaan wanneer er nog schulden bestaan. Op 28 juni 2021 is in dit kader het conceptwetsvoorstel Tijdelijke wet transparantie turboliquidatie voor internetconsultatie aangeboden.

Hoewel met dit conceptwetsvoorstel de eerste stappen naar een betere positie voor schuldeisers lijken te worden gezet, is het in zijn huidige vorm wat mij betreft slechts een doekje voor het bloeden. Het begint met het tijdelijk karakter van de voorgestelde wet; ook al vóór de COVID-19-pandemie werd de turboliquidatie als ontbindingswijze veelvuldig toegepast en ook buiten een pandemiesituatie verdienen schuldeisers een adequate bescherming. Buiten kijf staat dat het invoeren van een verantwoordingsplicht voor het bestuur in geval van turboliquidatie een stap in de goede richting is wat betreft transparantievergroting naar schuldeisers toe, maar ik betwijfel of misbruik van en fraude met turboliquidaties hierdoor beter worden bestreden. Van de nieuw voorgestelde vorm van de turboliquidatie kunnen fraudeurs nog altijd vrij eenvoudig misbruik maken; een misleidende slotbalans en bestuursverslag in de zin van artikel 2:19b BW lijken immers al voldoende.

De nieuwe wet dient ook met behulp van het nieuw te introduceren bestuursverbod in artikel 2:19c BW misbruik van turboliquidaties te bemoeilijken. Artikel 2:19c BW verwordt echter tot een lege huls wanneer deze bepaling niet wordt aangepast; slechts het Openbaar Ministerie krijgt de bevoegdheid een bestuursverbod in geval van een mogelijk malafide turboliquidatie te verzoeken. Het feit dat het civielrechtelijk bestuursverbod in faillissement in ruim vijf jaar tijd slechts vijf

44 Zie ook Renssen 2021, p. 78-89. 


\section{Maandblad}

Ondernemingsrecht

keer is verzocht door het Openbaar Ministerie schetst niet bepaald een rooskleurig beeld.

Gelet op de hoge aantallen turboliquidaties (zowel absoluut als relatief ten opzichte van reguliere ontbindingen en faillissementen) lijkt mij een uitgebreid onderzoek naar de gevolgen voor de maatschappij van (misbruik van) turboliquidaties op zijn plaats, hetgeen zou kunnen dienen als basis voor een nieuw, permanent wetsvoorstel inzake turboliquidaties. 